\title{
Graphite Furnace Atomic Absorption Spectrophotometric Determination of Trace Horseradish Peroxidase Using Nanosilver
}

\author{
Jiang Zhi-liang, ${ }^{*}$ Tang Ya-fang, Wei Lin, and Liang Ai-hui \\ Key Laboratory of Ecology of Rare and Endangered Species and Environmental Protection, the Ministry of Education, \\ School of Environment and Resource, Guangxi Normal University, Guilin 541004, P.R. China \\ E-mail: zljiang@mailbox.gxnu.edu.cn \\ Received April 7, 2011, Accepted July 4, 2011
}

\begin{abstract}
In $\mathrm{pH}$ 4.2 HAc-NaAc buffer solution, horseradish peroxidase (HRP) catalyzed $\mathrm{H}_{2} \mathrm{O}_{2}$ oxidation of nanosilver to form $\mathrm{Ag}^{+}$. After centrifugation, $\mathrm{Ag}^{+}$in the supernatant can be measured by graphite furnace atomic absorption spectrophotometry (GFAAS) at the silver absorption wavelength of $328.1 \mathrm{~nm}$. When HRP concentration increased, the $\mathrm{Ag}^{+}$concentration in the supernatant increased, and the absorption value enhanced. The HRP concentration in the range of $0.84-50 \mathrm{ng} \cdot \mathrm{mL}^{-1}$ was linear to the enhanced absorption value $(\Delta A)$, with a regression equation of $\Delta A=0.012 C+0.11$, correlation coefficient of 0.9988 , and detection limit of $0.41 \mathrm{ng} \cdot \mathrm{mL}^{-1}$ HRP. The proposed GFAAS method was used to detect HRP in waste water samples, with satisfactory results.
\end{abstract}

Key Words : Horseradish peroxidase, Nanosilver, Graphite furnace atomic absorption spectrophotometry

\section{Introduction}

Metal nanoparticles show unique optical and electrical properties owing to their surface, volume, quantum size and macroscopic quantum tunnel effect, and have been used in analytical chemistry. ${ }^{1-3}$ Nanosilver is a kind of the most affordable precious metal functional materials with high surface activity, and has been widely used as catalyst, antibacterial material, deodorant and ultraviolet radiation absorbent, and biosensor. Recently, it has been applied in biochemical analysis due to its novel spectral characteristics. ${ }^{4,5}$ Horseradish peroxidase (HRP) is a very important protease and can catalytically oxidize some inorganic and organic compounds, that utilized widely in the fields of environmental science, clinical chemistry, food industry, analytical chemistry and so on. ${ }^{6-12}$ Thus, its detection is very important. Presently, the main assays for detection of HRP activity including voltammetry, ${ }^{12}$ spectrophotometry, ${ }^{13-15}$ fluorescence spectrometry, ${ }^{16}$ chemiluminescence,${ }^{17}$ flow injection analysis, ${ }^{18}$ resonance scattering methods. ${ }^{19}$ The reagent of chromotrope $2 \mathrm{R}$ showed a voltammetric peak, and the peak decreased after adding $\mathrm{HRP}$ and $\mathrm{H}_{2} \mathrm{O}_{2}$. Accordingly, $4.0 \times 10^{-8}-4.0$ $\times 10^{-6} \mathrm{~g} \cdot \mathrm{mL}^{-1} \mathrm{HRP}$ can be determined by voltammetry. ${ }^{12}$ Using the system of quaternary ammonium- $\mathrm{H}_{2} \mathrm{O}_{2}-\mathrm{HRP}$, as low as $3 \times 10^{-10} \mathrm{~g} \cdot \mathrm{mL}^{-1} \mathrm{HRP}$ can be determined spectrophotometrically by enzyme-linked immunoassay. ${ }^{13}$ However, some of above method were not sensitive, some were not selective, and some method operations are complex. Atomic absorption spectrometry (AAS), especially graphite furnace atomic absorption spectrometry (GFAAS), is of high sensitivity and selectivity to determine metal elements, ${ }^{20,21}$ and recently applied in the indirect analysis of some organic compounds. ${ }^{22}$ Up to date, there is no report about GFAAS method for HRP using enzyme catalytic oxidation nanosilver reaction. Thus, establishing a highly selective and sensitive assay for HRP has a great significance. In this article, based on $\mathrm{H}_{2} \mathrm{O}_{2}$ oxidizing nanosilver to form $\mathrm{Ag}^{+}$in the presence of HRP catalyst, and measuring the $\mathrm{Ag}^{+}$in the supernatant by GFAAS, a highly sensitive and selective, and simple GFAAS assay has been proposed to detect HRP in water samples.

\section{Experimental}

Apparatus and Reagents. Model TAS-990 atomic absorption spectrometer (Beijing Puxi General Instrumental Company, China) was used to record silver absorption value with a measurement wavelength of $328.1 \mathrm{~nm}$, hollow cathode lamp current of $2.0 \mathrm{~mA}$, spectral band width of $0.4 \mathrm{~nm}$, measurement mode of the integration mode, measurement time of $3 \mathrm{~s}$, filter coefficients of 0.10 . Graphite furnace temperature program for silver was listed as in the Table 1. A model UV-1901 UV-visible spectrophotometer (Beijing Purkinje General Instrument Limited Co., China), a model XT-9900 intelligent microwave digestion instrument (Shanghai Xintuo Analytical Instruments Limited Co., China), a model RETBC1001 heating magnetic stirrer (IKA Group, Germany), a model Sigma 3K30 high speed freezing centrifuge (Sigma Company, Germany), a model SK1200H ultrasonic cleaner (Shanghai Kudos Ultrasonic Instrument Limited Co.,

Table 1. Parameters for the graphite furnace temperature program

\begin{tabular}{lcccc}
\hline Step & $\begin{array}{c}\text { Temperature Ramp time } \\
\left({ }^{\circ} \mathrm{C}\right)\end{array}$ & $\begin{array}{c}\text { Hold time } \\
(\mathrm{s})\end{array}$ & $\begin{array}{c}\text { Ar gas flow rate } \\
(\mathrm{mL} / \mathrm{min})\end{array}$ \\
\hline Drying & $80-100$ & 15 & 10 & 450 \\
Pyrolysis & 500 & 10 & 8 & 450 \\
Atomisation & 1800 & 0 & 3 & 0 \\
Clearing & 1900 & 1 & 2 & 450 \\
\hline
\end{tabular}


China), a model DK-8B thermostat (Shanghai Jing Hong Laboratory Instrument Limited Co., China), and a model PT$10 \mathrm{pH}$ meter (Sartorius, Germany) were used.

A $2.0 \times 10^{-3} \mathrm{~mol} \cdot \mathrm{L}^{-1} \quad \mathrm{AgNO}_{3}$ solution and $1 \%$ sodium citrate were prepared. $2.0 \times 10^{-3} \mathrm{~mol} \cdot \mathrm{L}^{-1}$ sodium borohydride $\left(\mathrm{NaBH}_{4}\right)$ were prepared freshly. Horseradish peroxidase $\left(3300 \mathrm{U} \cdot \mathrm{mg}^{-1}\right)$ was purchased from Huamei Biotechnology Company, China, and was used to prepare a $10 \mu \mathrm{g} \cdot \mathrm{mL}^{-1}$ solution with water. A $0.2 \mathrm{~mol} \cdot \mathrm{L}^{-1}$ acetic acid (HAc) and $0.2 \mathrm{~mol} \cdot \mathrm{L}^{-1}$ sodium acetate $(\mathrm{NaAc})$ were used to prepare $\mathrm{pH}$ 3.8-4.8 buffer solution (HAc-NaAc) according to a certain volume ratio. A $3.96 \times 10^{-2} \mathrm{~mol} \cdot \mathrm{L}^{-1}$ hydrogen peroxide $\left(\mathrm{H}_{2} \mathrm{O}_{2}\right)$ stock solution was standardized using potassium permanganate $\left(\mathrm{KMnO}_{4}\right)$ standard solution. All the reagents were analytical grade and the used water was doubly distilled.

Sodium Borohydride Reducing Procedure for Preparation of Nanosilver. Nanosilver was prepared by the following procedure. Firstly, $1.0 \mathrm{~mL}, 2.0 \mathrm{~mL}, 3.0 \mathrm{~mL}, 4.0$ $\mathrm{mL}, 6.0 \mathrm{~mL}, 9.0 \mathrm{~mL}, 10.0 \mathrm{~mL}, 12.0 \mathrm{~mL}, 13.0 \mathrm{~mL}, 18.0 \mathrm{~mL}$, $21.0 \mathrm{~mL}$ of $2.0 \times 10^{-3} \mathrm{~mol} \cdot \mathrm{L}^{-1} \mathrm{NaBH}_{4}$ were added to small beakers respectively. Then, $3.0 \mathrm{~mL}$ of $2.0 \times 10^{-3} \mathrm{~mol} \cdot \mathrm{L}^{-1}$ $\mathrm{AgNO}_{3}$ solution was dropped to beakers and stirred for 30 $\mathrm{min}$, The color changed to pale yellow, which indicated that the nanosilver particles formed. Finally, these solutions were transferred to $25 \mathrm{~mL}$ flasks, diluted to $25 \mathrm{~mL}$. Then $1.0 \mathrm{~mL}$ of solution was diluted to $3.0 \mathrm{~mL}$, the absorption value was measured by ultraviolet-visible spectrophotometer (Fig. 1). Results showed that, with addition of $\mathrm{NaBH}_{4}$, nanosilver concentration increased, and the absorption value enhanced. When the volume was greater than $10 \mathrm{~mL}$, the absorption value changed little, which indicated that $\mathrm{Ag}^{+}$had been reduced completely, and reducing agent had little effect. So, a $12.0 \mathrm{~mL} \mathrm{NaBH}_{4}$ was used to reduce $3.0 \mathrm{~mL}$ of $2.0 \times 10^{-3}$ $\mathrm{mol} \cdot \mathrm{L}^{-1} \mathrm{AgNO}_{3}$. The concentration, calculated as $\mathrm{Ag}$, was $2.4 \times 10^{-4} \mathrm{~mol} \cdot \mathrm{L}^{-1}$, the average size was $5 \mathrm{~nm}$, and the solution kept in dark place and stored at $4{ }^{\circ} \mathrm{C}$.

Sodium Citrate Microwave Reducing Procedure for Preparation of Nanosilver: A $1.2 \mathrm{~mL} 2.0 \times 10^{-3} \mathrm{~mol} \cdot \mathrm{L}^{-1}$ $\mathrm{AgNO}_{3}$ and $1.0 \mathrm{~mL} 1 \%$ sodium citrate were added in a digestion tank, mixed well and irradiated $4 \mathrm{~min}$ at $0.9 \mathrm{MPa}$

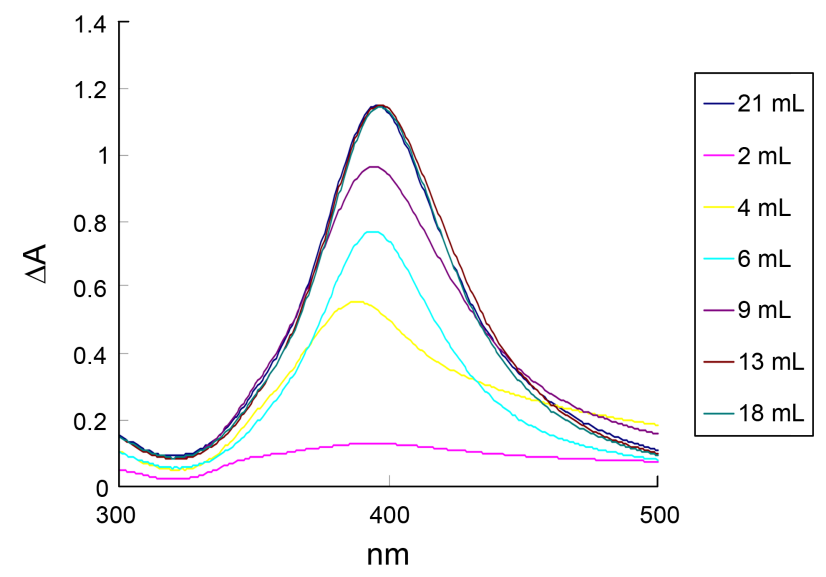

Figure 1. UV-vis absorption spectra of nanosilver. by microwave instrument. The mixture was diluted to 10 $\mathrm{mL}$, and was centrifuged at $9000 \mathrm{rpm}$ for $15 \mathrm{~min}$ to remove the supernatant. Then $10 \mathrm{~mL}$ water was added in the tube, and the particles were dispersed by ultrasounic wave for $15 \mathrm{~min}$, centrifuged twice by the same operation, and diluted to $10 \mathrm{~mL}$. The concentration, calculated as $\mathrm{Ag}$, was $2.4 \times 10^{-4} \mathrm{~mol} \cdot \mathrm{L}^{-1},{ }^{23}$ with average size of $10 \mathrm{~nm}$.

Sodium Citrate Heating Reducing Procedure for Preparation of Nanosilver. A $12.0 \mathrm{~mL} 2.0 \times 10^{-3} \mathrm{~mol} \cdot \mathrm{L}^{-1}$ $\mathrm{AgNO}_{3}$ solution and $100 \mathrm{~mL}$ water were added to a beaker. The solution was heated in water bath at $90{ }^{\circ} \mathrm{C}$. Then $5 \mathrm{~mL}$ of $1 \%$ sodium citrate solution was added slowly under stirring $(120 \mathrm{rpm})$ and the solution was kept at $90{ }^{\circ} \mathrm{C}$ for $60 \mathrm{~min}$. Then it was transferred into a $100 \mathrm{~mL}$ volumetric flask, and diluted to the mark. The concentration, calculated as $\mathrm{Ag}$, was $2.4 \times 10^{-4} \mathrm{~mol} \cdot \mathrm{L}^{-1}$, with an average size of $15 \mathrm{~nm}$. Finally, the solution was centrifuged and purified as same as above operation, and was kept in dark place and stored at $4{ }^{\circ} \mathrm{C}$.

Procedure for Assay of HRP. A $100 \mu \mathrm{L}$ of $\mathrm{pH} 4.2 \mathrm{HAc}-$ NaAc buffer solution, $40 \mu \mathrm{L} 3.96 \times 10^{-2} \mathrm{~mol} \cdot \mathrm{L}^{-1} \mathrm{H}_{2} \mathrm{O}_{2}$ solution, $1.0 \mathrm{~mL} 2.4 \times 10^{-4} \mathrm{~mol} \cdot \mathrm{L}^{-1}$ silver colloid, and a certain amount of HRP were added to a $5 \mathrm{~mL}$ graduated tube successively. The mixture was diluted to $3.0 \mathrm{~mL}$ and reacted for $6 \mathrm{~min}$ at $30^{\circ} \mathrm{C}$. Then, the mixture was centrifuged at $24000 \mathrm{rpm}$ for $20 \mathrm{~min}$ to obtain the supernatant. A $100 \mu \mathrm{L}$ of the supernatant was added to a $5 \mathrm{~mL}$ graduated tube, and diluted to $2.0 \mathrm{~mL}$. The absorption value at $328.1 \mathrm{~nm}(A)$ was recorded by atomic absorption spectrometry. The $A_{b}$ value of the blank solution without HRP was also measured. The value of $\Delta A=A-A_{b}$ was calculated.

\section{Results and Discussion}

Principle. Nanosilver particles are oxidized difficultly by $\mathrm{H}_{2} \mathrm{O}_{2}$ in weak acid condition. Upon addition of HRP catalyst, it can catalyze $\mathrm{H}_{2} \mathrm{O}_{2}$ to generate hydroxyl radical, which has strong oxidation, and can oxidize nanosilver particles to form silver ions. According to our results and the references,${ }^{19}$ the main reactions are as follows,

$$
\begin{gathered}
\mathrm{HRP}+\mathrm{H}_{2} \mathrm{O}_{2} \stackrel{\text { Catalyzed }}{\longrightarrow} \longrightarrow \cdot \mathrm{OH} \\
(\mathrm{Ag})_{\mathrm{n}}+\cdot \mathrm{OH} \longrightarrow \mathrm{Ag}^{+}+\mathrm{OH}^{-}
\end{gathered}
$$

According to above reactions, we know,

$$
\begin{aligned}
& C \cdot \mathrm{OH} \propto C_{\mathrm{HRP}} \\
& C_{\mathrm{Ag}+} \propto C \cdot \mathrm{OH}
\end{aligned}
$$

Where $C \cdot{ }_{\text {OH }}, C_{\mathrm{HRP}}$ and $C_{\mathrm{Ag}+}$ stand for the concentration of hydroxyl radicals, HRP and $\mathrm{Ag}^{+}$respectively. Based on AAS principle, we have known,

$$
A \propto C_{\mathrm{Ag}+}
$$

According to formula (3)-(5), we get,

$$
A \propto C_{\mathrm{Ag}+} \propto C \cdot \mathrm{OH}_{1} \propto C_{\mathrm{HRP}}
$$

The formula (6) indicated that when HRP concentration 


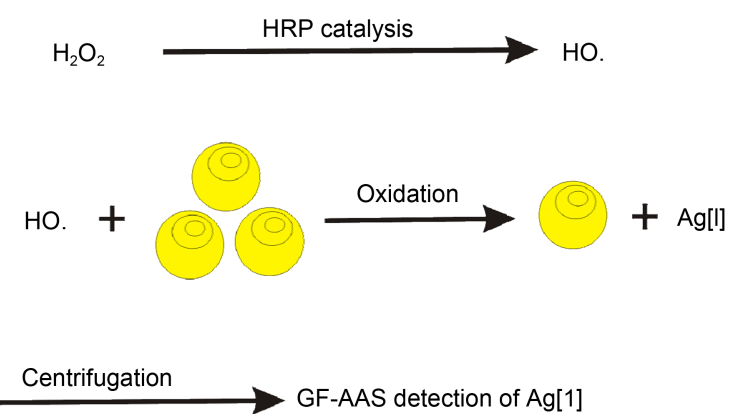

Figure 2. Principle of GFAAS assay of HRP.

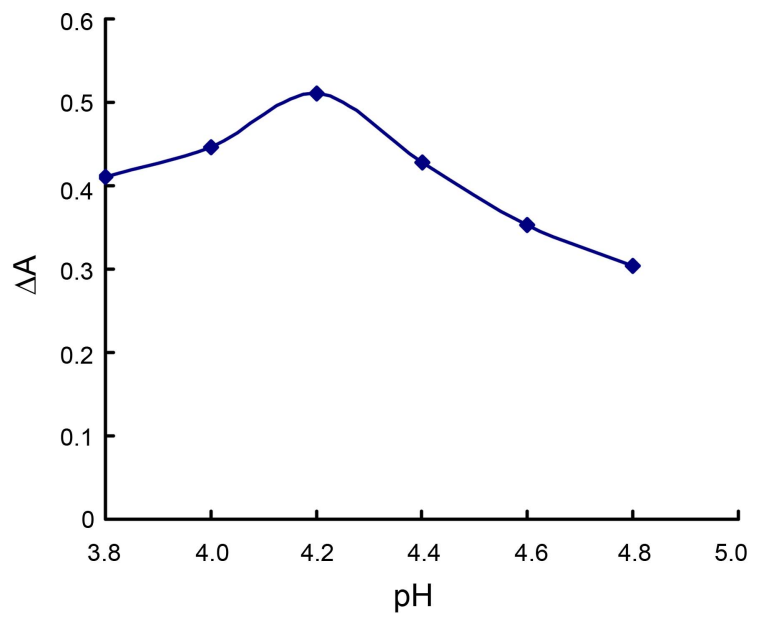

Figure 3. Effect of $\mathrm{pH}$.

$26.4 \mu \mathrm{mol} \cdot \mathrm{L}^{-1} \mathrm{H}_{2} \mathrm{O}_{2}-40 \mu \mathrm{mol} \cdot \mathrm{L}^{-1}$ nanosilver $-33.3 \mathrm{ng} \cdot \mathrm{mL}^{-1} \mathrm{HRP}$.

increased the concentration of hydroxyl radical increased, the amount of oxidized nanosilver particles increased, the $\mathrm{Ag}^{+}$concentration in the supernatant increased, and the absorption value increased linearly. Based on these grounds, a rapid, sensitive and selective GFAAS assay for HRP was established (Fig. 2).

Influence of Adding Reagents Sequence. The adding sequence of buffer solution, $\mathrm{H}_{2} \mathrm{O}_{2}$, HRP, and nanosilver was studied. As Table 2 showed that the $\Delta A$ value was minimal, when the adding sequence was buffer solution+ nanosilver $+\mathrm{H}_{2} \mathrm{O}_{2}+\mathrm{HRP}$ was used. The $\Delta A$ value was maximal when adding sequence of buffer solution $+\mathrm{H}_{2} \mathrm{O}_{2}+$ nanosilver+ HRP was selected for use.

Effect of pH. Effect of $\mathrm{pH}$ HAc-NaAc buffer solution in the range of 3.8-4.8 was considered. Figure 3 showed that when the $\mathrm{pH}$ value was 4.2 , the most hydroxyl radicals formed, and the $\Delta A$ was maximal. With addition volume of buffer solution increased, the absorption value increased. But the $\mathrm{Ac}^{-}$concentration was higher than $10 \mathrm{mmol} \cdot \mathrm{L}^{-1}$, the blank absorption increased. Thus, a $0.1 \mathrm{~mL}$ pH 4.2 HAc-

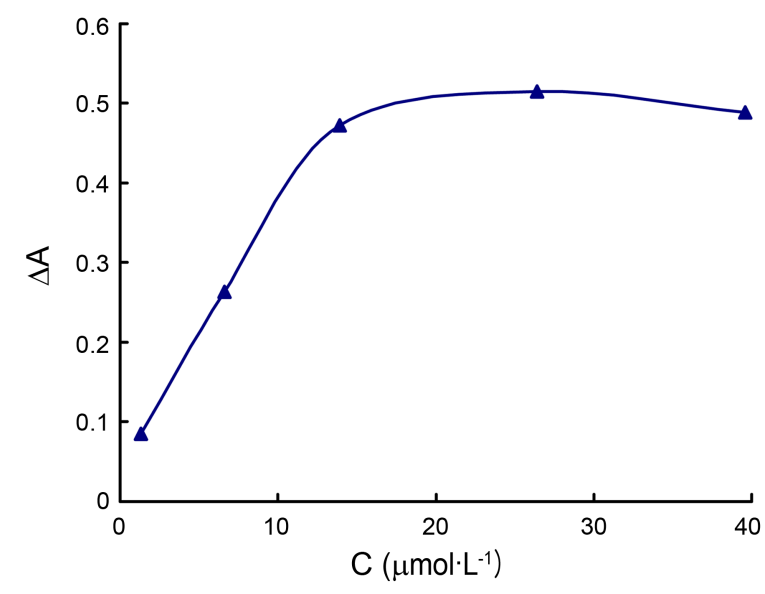

Figure 4. Effect of $\mathrm{H}_{2} \mathrm{O}_{2}$ concentration. $\mathrm{pH} 4.2 \mathrm{HAc}-\mathrm{NaAc}-40 \mu \mathrm{mol} \cdot \mathrm{L}^{-1}$ nanosilver $-33.3 \mathrm{ng} \cdot \mathrm{mL}^{-1} \mathrm{HRP}$.

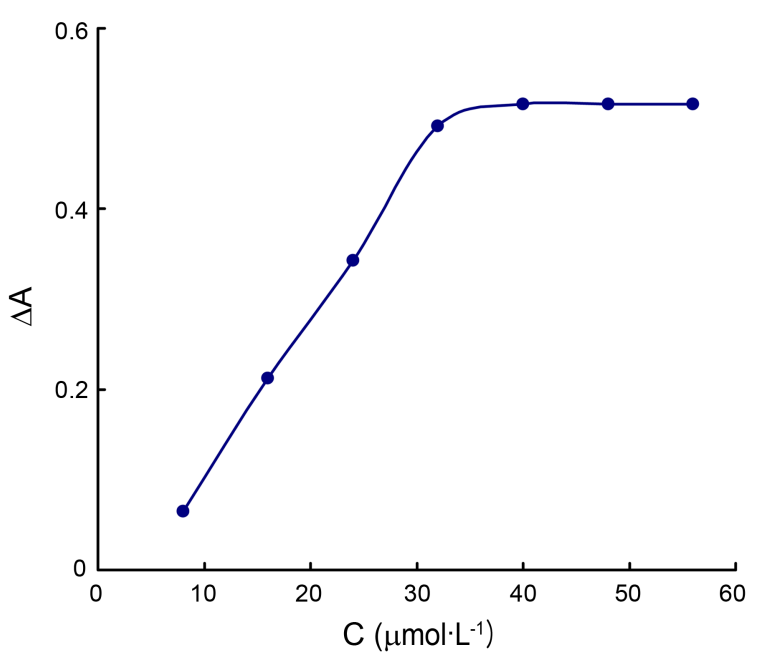

Figure 5. Effect of nanosilver concentration.

$\mathrm{pH}$ 4.2 HAc-NaAc $-26.4 \mu \mathrm{mol} \cdot \mathrm{L}^{-1} \mathrm{H}_{2} \mathrm{O}_{2}-40 \mu \mathrm{mol} \cdot \mathrm{L}^{-1}$ nanosilver $33.3 \mathrm{ng} \cdot \mathrm{mL}^{-1} \mathrm{HRP}$.

$\mathrm{NaAc}$ buffer solution with the concentration of $6.67 \mu \mathrm{mol} \cdot \mathrm{L}^{-1}$ $\mathrm{Ac}^{-}$was used.

Effect of $\mathrm{H}_{2} \mathrm{O}_{2}$ Concentration. Effect of $\mathrm{H}_{2} \mathrm{O}_{2}$ concentration in the range of $1.32-39.6 \mu \mathrm{mol} \cdot \mathrm{L}^{-1}$ on the $\Delta A$ was studied. Results showed that when the $\mathrm{H}_{2} \mathrm{O}_{2}$ concentration was in the range of $1.32-26.4 \mu \mathrm{mol} \cdot \mathrm{L}^{-1}$, the formed hydroxyl radical increased and the absorption value increased with the $\mathrm{H}_{2} \mathrm{O}_{2}$ concentration. When the $\mathrm{H}_{2} \mathrm{O}_{2}$ concentration was $26.4 \mu \mathrm{mol} \cdot \mathrm{L}^{-1}$, the formed hydroxyl radical was most, and the $\Delta A$ was maximal (Fig. 4). Thus, a concentration of $26.4 \mu \mathrm{mol} \cdot \mathrm{L}^{-1} \mathrm{H}_{2} \mathrm{O}_{2}$ was used.

Effect of Nanosilver Concentration. The effect of nanosilver concentration on the $\Delta A$ was considered. Results showed in Figure 5. When nanosilver concentration increased,

Table 2. The influence of adding reagents sequence on $\Delta A$

\begin{tabular}{ccccc}
\hline Sequence & $\begin{array}{c}\text { buffer solution }+ \\
\text { nanosilver }+\mathrm{H}_{2} \mathrm{O}_{2}+\mathrm{HRP}\end{array}$ & $\begin{array}{c}\text { buffer solution }+\mathrm{H}_{2} \mathrm{O}_{2} \\
+\mathrm{HRP}+\text { nanosilver }\end{array}$ & $\begin{array}{c}\text { buffer solution }+\mathrm{H}_{2} \mathrm{O}_{2} \\
+ \text { nanosilver }+\mathrm{HRP}\end{array}$ & $\begin{array}{c}\text { buffer solution }+\mathrm{HRP} \\
+ \text { nanosilver }+\mathrm{H}_{2} \mathrm{O}_{2}\end{array}$ \\
\hline$\Delta A$ & 0.486 & 0.502 & 0.521 & 0.495 \\
\hline
\end{tabular}




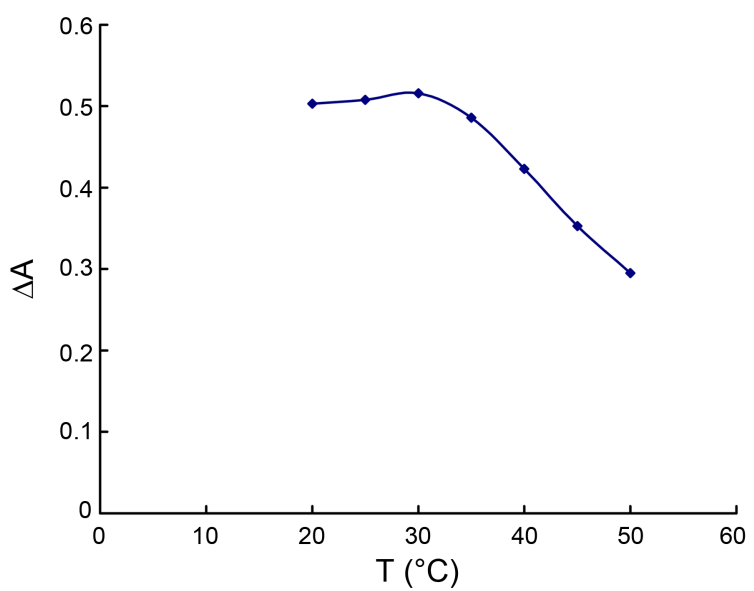

Figure 6. Effect of temperature.

$\mathrm{pH} 4.2 \mathrm{HAc}-\mathrm{NaAc}-26.4 \mu \mathrm{mol} \cdot \mathrm{L}^{-1} \quad \mathrm{H}_{2} \mathrm{O}_{2}-40 \mu \mathrm{mol} \cdot \mathrm{L}^{-1}$ silver nanoparticles $-33.3 \mathrm{ng} \cdot \mathrm{mL}^{-1} \mathrm{HRP}$.

the oxidized nanosilver increased, and the $\Delta A$ value enhanced greatly. When the nanosilver concentration was $40 \mu \mathrm{mol} \cdot \mathrm{L}^{-1}$, the $\Delta A$ value was maximal. The nanosilver increased further, the absorption value changed little, it indicated that the amount of nanosilver was enough, so a $40 \mu \mathrm{mol} \cdot \mathrm{L}^{-1}$ nanosilver was used. In this assay, because the absorption value of $\mathrm{Ag}^{+}$concentration in the supernatant was measured, the relationship between $\mathrm{Ag}^{+}$concentration and absorption value was examined. Results showed the absorption value was linear to $\mathrm{Ag}^{+}$concentration in the range of $2.0 \times 10^{-8}-1.2 \times 10^{-6} \mathrm{~mol} \cdot \mathrm{L}^{-1}$, with a regression equation of $A=0.6886 C_{\mathrm{Ag}}+0.0595$, and relative coefficient of 0.9952 , thus the supernatant was diluted before measured.

Effects of Reaction Temperature and Reaction Time. Enzyme is a kind of protein, and the protein will deteriorate and lose their activity if the temperature is too high, so the temperature on the catalytic reaction has a great influence. In this article, the effect of temperature $\left(20-50{ }^{\circ} \mathrm{C}\right)$ on the $\Delta A$ value was examined. Figure 6 showed that the $\Delta A$ reached maximum at $30^{\circ} \mathrm{C}$. The $\Delta A$ values decreased greatly as the reaction temperature was higher than $35^{\circ} \mathrm{C}$. When the reaction time was $6 \mathrm{~min}$, the $\Delta A$ value was maximal and kept stable within $40 \mathrm{~min}$. Thus, reaction time $6 \mathrm{~min}$ at $30^{\circ} \mathrm{C}$ was chosen for use.

Effect of Centrifugation Speed and Time. The effect of centrifugation speed and time on the $\Delta A$ value was studied, respectively. Results showed that the centrifugation speed was in the range of $16000-26000 \mathrm{rpm}$, the $\Delta A$ increased (Fig. 7). When the centrifugation speed was higher than

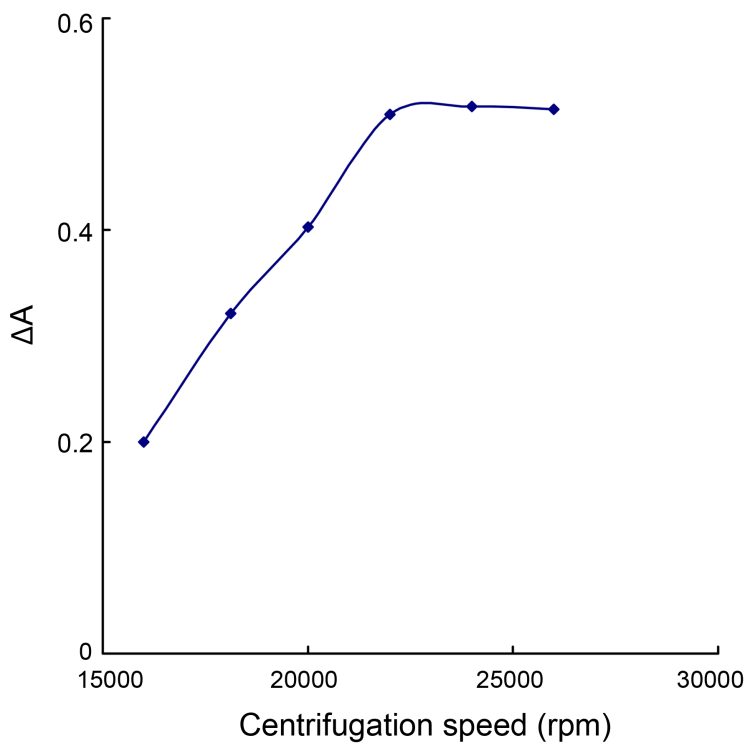

Figure 7. Effect of centrifugation speed on $\triangle A$. $\mathrm{pH} 4.2 \mathrm{HAc}-\mathrm{NaAc}-26.4 \mu \mathrm{mol} \cdot \mathrm{L}^{-1} \mathrm{H}_{2} \mathrm{O}_{2}-40 \mu \mathrm{mol} \cdot \mathrm{L}^{-1}$ silver nanoparticles $-33.3 \mathrm{ng} \cdot \mathrm{mL}^{-1} \mathrm{HRP}$.

$24000 \mathrm{rpm}$ (centrifugation force was 48942RCF), the $\Delta A$ was reached maximum. When the centrifugation time was within $20 \mathrm{~min}$, the $\Delta A$ value reached maximum and stabilized. Thus, $24000 \mathrm{rpm}$ for $20 \mathrm{~min}$ was chosen.

Working Curve. According to the procedure, the $\Delta A$ value for different HRP concentrations $C\left(\mathrm{ng} \cdot \mathrm{mL}^{-1}\right)$ was recorded. The analytical features of the nanosilver on the $\Delta A$ were showed in Table 3. The nanosilver prepared by the sodium borohydride reduction procedure had a low detection limit and wide detection range. For this nanosilver,

Table 4. Selectivity of the method (33.3 ng $\left.\mathrm{mL}^{-1} \mathrm{HRP}\right)$

\begin{tabular}{ccc|ccc}
\hline $\begin{array}{c}\text { Coexisting } \\
\text { Substance }\end{array}$ & $\begin{array}{c}\text { Tolerance } \\
{[\mathrm{CS}] /} \\
{[\mathrm{HRP}]}\end{array}$ & $\begin{array}{c}\text { Relative } \\
\text { error } \\
(\%)\end{array}$ & $\begin{array}{c}\text { Coexisting } \\
\text { Substance }\end{array}$ & $\begin{array}{c}\text { Tolerance } \\
{[\mathrm{CS}] /} \\
{[\mathrm{HRP}]}\end{array}$ & $\begin{array}{c}\text { Relative } \\
\text { error } \\
(\%)\end{array}$ \\
\hline $\mathrm{Mg}^{2+}$ & 210 & +5.1 & $\mathrm{Mn}^{2+}$ & 160 & -5.8 \\
$\mathrm{~Pb}^{2+}$ & 200 & +5.3 & $\mathrm{Cr}^{3+}$ & 90 & +3.6 \\
$\mathrm{Al}^{3+}$ & 80 & -6.7 & $\mathrm{Zn}^{2+}$ & 220 & +6.3 \\
$\mathrm{Fe}^{3+}$ & 90 & +6.1 & $\mathrm{Ni}^{2+}$ & 210 & +5.3 \\
$\mathrm{Co}^{2+}$ & 300 & -3.7 & $\mathrm{Hg}^{2+}$ & 150 & -4.7 \\
$\mathrm{Ca}^{2+}$ & 250 & +5.8 & $\mathrm{Cl}^{-}$ & 150 & -5.5 \\
$\mathrm{~K}^{+}$ & 400 & -7.5 & $\mathrm{NO}_{3}{ }^{-}$ & 300 & -6.1 \\
$\mathrm{NH}_{4}^{+}$ & 380 & +4.5 & $\mathrm{CO}_{3}^{2-}$ & 240 & +4.4 \\
$\mathrm{Cd}^{3+}$ & 180 & +6.5 & $\mathrm{SO}_{4}{ }^{2-}$ & 300 & -3.6 \\
\hline \multicolumn{7}{r}{}
\end{tabular}

Table 3. Analytical features of the different nanosilver systems

\begin{tabular}{ccccc}
\hline Nanosilver size & Regression equation & $\begin{array}{c}\text { Linear range } \\
\left(\mathrm{ng} \cdot \mathrm{mL}^{-1}\right)\end{array}$ & $\begin{array}{c}\text { Detection limits } \\
\left(\mathrm{ng} \cdot \mathrm{mL}^{-1}\right)\end{array}$ & Correlation coefficient \\
\hline $5 \mathrm{~nm}^{a}$ & $\Delta A=0.012 C+0.11$ & $0.84-50.0$ & 0.41 & 0.9988 \\
$10 \mathrm{~nm}^{b}$ & $\Delta A=0.0062 C+0.23$ & $2.08-33.3$ & 1.27 & 0.9983 \\
$15 \mathrm{~nm}^{c}$ & $\Delta A=0.0051 C+0.01$ & $0.84-33.3$ & 0.60 & 0.9968 \\
\hline
\end{tabular}

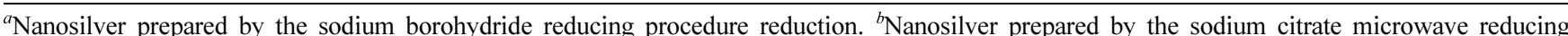
procedure reduction. ${ }^{c}$ Nanosilver prepared sodium citrate heating reducing procedure reduction. 
Table 5. Analytical results for HRP concentration and recovery in samples

\begin{tabular}{ccccccc}
\hline Sample & $\begin{array}{c}\text { Single value } \\
\left(\mathrm{ng} \cdot \mathrm{mL}^{-1}\right)\end{array}$ & $\begin{array}{c}\text { Average } \\
\left(\mathrm{ng} \cdot \mathrm{mL}^{-1}\right)\end{array}$ & $\begin{array}{c}\text { RSD } \\
(\%)\end{array}$ & $\begin{array}{c}\text { Added } \\
\left(\mathrm{ng} \cdot \mathrm{mL}^{-1}\right)\end{array}$ & $\begin{array}{c}\text { Found } \\
\left(\mathrm{ng} \cdot \mathrm{mL}^{-1}\right)\end{array}$ & $\begin{array}{c}\text { Recovery } \\
\%\end{array}$ \\
\hline 1 & $8.42,8.61,8.72,8.55,8.67$ & 8.59 & 1.4 & 16.67 & 16.82 & 100.9 \\
2 & $2.85,2.72,2.79,2.63,2.78$ & 2.75 & 3.0 & 16.67 & 15.73 & 94.4 \\
3 & $14.6,15.7,15.0,14.8,16.1$ & 15.24 & 4.2 & 16.67 & 16.26 & 97.5 \\
\hline
\end{tabular}

as the size reduced (about $5 \mathrm{~nm}$ ), the surface enlarged, so the oxidation of nanosilver by $\mathrm{H}_{2} \mathrm{O}_{2}$ enhanced, the slope value increased, and a lower detection limit can be achieved. So this nanosilver was chosen for determination of HRP.

Influence of Foreign Substances. According to the procedure, the influence of foreign substance on the determination of $33.3 \mathrm{ng} \cdot \mathrm{mL}^{-1} \mathrm{HRP}$ was examined, with a relative error of $\pm 10 \%$. Tolerance of weight ratio of coexistence ions was shown in Table 4. Some common ions did not significantly interfere with the HRP determination. Thus, this assay has good selectivity.

Determination of Sample. Appropriate waste water was filtered and determined according to the procedure. The results were showed in Table 5. A known amount of HRP was added to the samples to determine recovery, and the recovery was $94.4-100.9 \%$.

Acknowledgments. This work was supported by the National Natural Science Foundation of China (Nos. 21075023, 20965002, 20865002), Natural Science Foundation of Guangxi (No.0991021z) and the Research Funds of Guangxi Water Conservancy.

\section{References}

1. Guo, C.-X.; Paul, B.; Jiang, L.; Liu, T. Biosens. Bioelectron. 2007, 22, 1830.

2. Yuan, J.; Oliver, R.; Li, J.; Lee, J. Biosens. Bioelectron. 2007, 23, 144.

3. Zhang, L.-Y.; Yuan, R.; Huang, X.-Q.; Chai, Y.-Q.; Tang, D.-P.; Cao, S.-R. Anal. Bioanal. Chem. 2005, 381, 1036.
4. Wei, X.-L.; Zhang, Y.-L.; Jiang, Z.-L. Spectrosc. Spect. Anal. 2009, 29, 1640 .

5. Liang, A.-H.; Zhang, N.-N.; Jiang, Z.-L.; Liu, R.-J. Sci. Chin. Ser. $B$ 2008, 51, 1932.

6. Li, Z.-Q.; Xu, X.-P.; Yang, H.-L.; Wang, W. Chin. J. Anal. Chem. 2006, 34, 821.

7. Song, G.-L.; Jia, S.-Z.; Guo, Y.-C.; Tian, Y.-F. Chin. J. Anal. Chem. 2007, 35, 731 .

8. Zhang, J.; Xu, J.-J.; Chen, H.-Y. Chem. J. Chin. Univ. 2004, 25 , 614.

9. Zhang, L.-Y.; Yuan, R.; Chai, Y.-Q.; Cao, S.-R.; Li, X.-L.; Wang, N. Acta Chim. Sin. 2006, 64, 1711.

10. Zhu, Z.-H.; Li, X.; Wang, Y.; Zeng, Y.; Sun, W.; Huang, X.-T. Anal. Chim. Acta 2010, 670, 51-56.

11. Yuan, Y.-M.; Li, J.-P. Chin. J. Anal. Chem. 2007, 35, 1078.

12. Jiao, K.; Xu, J.; Shun, W.; Jiang, H. Chin. J. Anal. Chem. 2004, $32,593$.

13. Li, J.-G.; Liu, Y.; Ju, H.-X. Acta Chim. Sin. 2007, 65, 1499.

14. Wei, Y.-F.; Yan, H.-T. Spectrosc. Spect. Anal. 2001, 21, 704.

15. Reichhart, C.; Czeslik, C. Colloid. Surface B 2010, 5, 612.

16. Zhang, S.-S.; Jiao, K.; Ji, X.-F. Qingdao Inst. Chem. Technol. (Natural Ed.) 1997, 18(4), 333.

17. Iwata, R.; Ito, H.; Hayashi, T.; Sekine, Y.; Koyama, N.; Yamaki, M. Anal. Biochem. 1995, 231, 170.

18. Salinas, E.; Torriero, A.-A.-J.; Sanz, M.-I.; Battaglini, F.; Raba, J. Talanta 2005, 66, 92.

19. Jiang, Z.-L.; Liang, Y.-Y.; Huang, G.-X.; Wei, X.-L.; Liang, A.-H. Zhong, F.-X. Luminesc. 2009, 24, 144.

20. Zhang, Y.-L.; Adeloju, S.-B. Talanta 2008, 74, 951.

21. Li, S.-Q.; Cai, S.; Hu, W.; Chen, H.; Liu, H.-L. Spectrochim. Acta Part B 2009, 64, 666.

22. Dong, Z.-M.; Xin, H.-L.; Zheng, Y.-Z.; Sun, Q.-L.; Zhang, Y. Spectrosc. Spect. Anal. 2007, 27, 1862.

23. Jiang, Z.-L.; Liu, Q.-Y.; Liu, S.-P. Spectrochim Acta A 2002, 58, 2759. 